Article

\title{
Improving the Retrieval of Carbon-Based Phytoplankton Biomass from Satellite Ocean Colour Observations
}

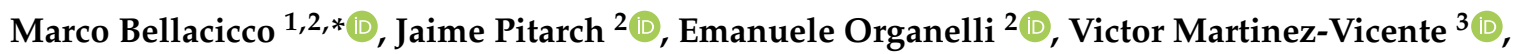 \\ Gianluca Volpe ${ }^{2}$ and Salvatore Marullo ${ }^{1,2}$ D \\ 1 Climate Modelling Laboratory, Italian National Agency for New Technologies, Energy and Sustainable \\ Economic Development (ENEA), Via E. Fermi 45, 00044 Frascati, Italy; salvatore.marullo@enea.it \\ 2 Consiglio Nazionale delle Ricerche (CNR), Istituto di Scienze Marine (ISMAR), Via Fosso del Cavaliere, \\ 100 Rome, Italy; jaime.pitarchportero@artov.ismar.cnr.it (J.P.); emanuele.organelli@cnr.it (E.O.); \\ gianluca.volpe@cnr.it (G.V.) \\ 3 Plymouth Marine Laboratory (PML), Prospect Place, The Hoe, Plymouth PL1 3DH, UK; vmv@pml.ac.uk \\ * Correspondence: marco.bellacicco@enea.it
}

Received: 2 October 2020; Accepted: 3 November 2020; Published: 6 November 2020

\begin{abstract}
Phytoplankton is at the base of the marine food web and plays a fundamental role in the global carbon cycle. Ongoing climate change significantly impacts phytoplankton distribution in the ocean. Monitoring phytoplankton is crucial for a full understanding of changes in the marine ecosystem. To observe phytoplankton from space, chlorophyll- $a$ concentration (Chl) has been widely used as a proxy of algal biomass, although it can be impacted by physiology. Therefore, there has been an increasing focus towards estimating phytoplankton biomass in units of carbon $\left(\mathrm{C}_{\text {phyto }}\right)$. Here, we developed an algorithm to quantify $\mathrm{C}_{\text {phyto }}$ from space-based observations that accounts for the spatio-temporal variations of the backscattering coefficient associated with the fraction of detrital particles that do not covary with $\mathrm{Chl}$. The main findings are: (i) a spatial and temporal variation of the detritus component must be accounted for in the $\mathrm{C}_{\text {phyto }}$ algorithm; (ii) the refined $\mathrm{C}_{\text {phyto }}$ algorithm performs better (relative bias of $23.7 \%$ ) than any previously existing model; and (iii) our algorithm shows the lowest error in $\mathrm{C}_{\text {phyto }}$ across areas where picophytoplankton dominates (relative bias of $14 \%)$. In other areas, it is currently not possible to accurately assess the performance of the refined algorithm due to the paucity of in situ carbon data associated with nano- and micro-phytoplankton size classes.
\end{abstract}

Keywords: phytoplankton carbon; optical backscattering; non-algal particles; ocean colour observations; QAA algorithm; ESA OC-CCI

\section{Introduction}

Phytoplankton is responsible for approximately half of global primary production and is at the base of the marine food web [1]. Phytoplankton is consequently a fundamental actor in the global carbon cycle [2]. Moreover, these organisms are regarded as sentinels of changes in the ocean because of their capacity to respond rapidly to environmental perturbations. Several factors, such as ocean circulation, anthropogenic activities, and climate affect phytoplankton abundance and distribution. In particular, phytoplankton spatio-temporal patterns are expected to vary with climate change [3]. Monitoring the distribution of phytoplankton is crucial for a full understanding of the oceanic biogeochemical cycles.

Ocean colour observations have significantly improved our capability to map phytoplankton global distribution since the 1970 s. Chlorophyll-a concentration $\left(\mathrm{Chl} ; \mathrm{in} \mathrm{mg} \mathrm{m}^{-3}\right)$ is a consolidated proxy of algal biomass [4]. However, Chl variability may not always correspond to actual changes in algal 
biomass but rather to cellular physiological adjustments in response to environmental stressors such as light and nutrient limitation $[5,6]$. Therefore, there has been an increasing focus on the estimation of phytoplankton biomass in units of carbon $\left(\mathrm{C}_{\text {phyto }} ; \mathrm{mg} \mathrm{C} \mathrm{m}^{-3}\right) . \mathrm{C}_{\text {phyto }}$ has found application in studies of: (i) primary production [7,8]; (ii) phytoplankton physiology [9]; (iii) phytoplankton growth/loss rates [10,11]; (iv) comparison with marine ecosystem models [12]; (v) pools of carbon in the ocean (i.e., their stocks and turnover rates); and (vi) ocean-atmosphere interactions in marine phytoplankton feedback in atmospheric aerosols [13].

Martinez-Vicente et al. (2017) recently reviewed algorithms for deriving $C_{\text {phyto }}$ from satellite ocean colour observations [14]. Three groups of algorithms are currently available: (i) backscatter-based models developed using satellite [7] or in situ data [14-16]; (ii) Chl-based models [17,18]; and (iii) allometric conversion-based models [19-21]. Among these algorithms, those relying on the particulate optical backscattering coefficient, $b_{\mathrm{bp}}\left(\right.$ in $\mathrm{m}^{-1}$ ), raised high interest because $b_{\mathrm{bp}}$ is related to the concentration and composition of suspended particles in seawater, and to their size and shape [22]. Although former research suggested that $b_{\mathrm{bp}}$ was mainly influenced by submicron detrital particles [22], it has recently been demonstrated that most of the $b_{\mathrm{bp}}$ signal in the surface oligotrophic ocean is due to particles with equivalent spherical diameters between 1 and $10 \mu \mathrm{m}$ [23], thus reinforcing the role of phytoplankton as a source of the open-ocean $b_{\mathrm{bp}}$ [24], and thus the usefulness of $b_{\mathrm{bp}}$ to retrieve $\mathrm{C}_{\text {phyto }}$. However, satellite $b_{\mathrm{bp}}$-based algorithms show large errors in predicting $\mathrm{C}_{\text {phyto }}$ mainly because the current formulation does not take into account the spatio-temporal changes of non-algal particles (NAP) [25].

Here we refine the first and widely applied satellite $b_{\mathrm{bp}}$-based $\mathrm{C}_{\text {phyto }}$ model [7] and make crucial arrangements to improve its performance. Beh05 uses the linear relationship between Chl and $b_{\mathrm{bp}}$ to estimate the background contribution of NAP to $b_{\mathrm{bp}}(443), b_{\mathrm{bp}}^{\mathrm{k}}$, which corresponds to $b_{\mathrm{bp}}$ when Chl is zero (i.e., the intercept of the linear fit). Beh05 is based on the following equation:

$$
\mathrm{C}_{\text {phyto }}=\left[b_{\mathrm{bp}}(443)-b_{\mathrm{bp}}^{\mathrm{k}}\right] \cdot \mathrm{SF}
$$

In Beh05, SF is the scaling factor used to convert $b_{\mathrm{bp}}$ into $\mathrm{C}_{\text {phyto }}$ and is set to $13,000 \mathrm{mg} \mathrm{C} \mathrm{m}^{-2}$ [7]. $b_{\mathrm{bp}}^{\mathrm{k}}$ is assumed to represent a stable surface population of heterotrophic and detrital particles that is not strictly dependent on phytoplankton dynamics and physiology. Thus, in Beh05, $b_{\mathrm{bp}}^{\mathrm{k}}$ was assumed as a constant value $\left(3.5 \cdot 10^{-4} \mathrm{~m}^{-1}\right)$. However, NAP can include various types of particles ranging from heterotrophic organisms such as bacteria, micrograzers, and viruses, to fecal pellets and cell debris, and mineral particles and bubbles [22] that vary both in space and time. The nature, definition, and evaluation of $b_{\mathrm{bp}}^{\mathrm{k}}$ is still under debate and has been investigated using in situ [24-26] and satellite data $[27,28]$. Understanding the spatial and temporal dynamics of $b_{\mathrm{bp}}^{\mathrm{k}}$ in the open ocean will improve estimations of $\mathrm{C}_{\text {phyto }}$ and, more generally, our knowledge on the fate of marine carbon.

Beh05 estimated $b_{\mathrm{bp}}^{\mathrm{k}}$ as the offset (intercept) of the least-square regression between monthly satellite-derived $b_{\mathrm{bp}}$ and Chl computed via the Garver-Siegel-Maritorena (GSM) semi-analytical algorithm [29]. The regression analysis used only Chl values higher than $0.14 \mathrm{mg} \mathrm{m}^{-3}$ to separate the changes in Chl due to physiology (i.e., photoacclimation) from actual changes in biomass, and thus in $\mathrm{C}_{\text {phyto }}$. Bellacicco et al. (2018) used satellite data from the Mediterranean Sea to estimate $b_{\mathrm{bp}}^{\mathrm{k}}$ for various bioregions and seasons, and showed that $b_{\mathrm{bp}}^{\mathrm{k}}$ varied regionally and seasonally, thus rejecting the hypothesis of invariance of the heterotrophic and detrital components at the sea surface [27]. Global variability in $b_{\mathrm{bp}}^{\mathrm{k}}$ was observed [28], with a reported median global value of $9.510^{-4} \mathrm{~m}^{-1}$, nearly threefold that found by Beh05. The newly evaluated $b_{\mathrm{bp}}^{\mathrm{k}}$ resulted in $\mathrm{C}_{\text {phyto }}$ that were half those estimated by Beh05.

The Chl- $b_{\mathrm{bp}}$ relationship is influenced by phytoplankton specific composition and diversity (e.g., size, shape, internal structure), physiology (e.g., photoacclimation), and the nature of NAP itself [22,30,31]. For these reasons, Brewin et al. (2012) (hereafter Bre12; [26]) developed an analytical 
non-linear fit between $b_{\mathrm{bp}}$ and $\mathrm{Chl}$ that accounted for changes in phytoplankton cell size. In Bre12, the offset of the non-linear fit (i.e., $b_{\mathrm{bp}}^{\mathrm{k}}$ ) between $b_{\mathrm{bp}}$ and $\mathrm{Chl}$ in clear waters was interpreted as a constant background of NAP or also partly influenced by very small phytoplankton (e.g., prochlorophytes) in addition to NAP. In Bre12, the reported $b_{\mathrm{bp}}^{\mathrm{k}}$ values were $7.0 \cdot 10^{-4} \mathrm{~m}^{-1}$ at the wavelength of $470 \mathrm{~nm}$ and $5.6 \cdot 10^{-4} \mathrm{~m}^{-1}$ at $526 \mathrm{~nm}$. More recently, the Bre12 model was used with a large database of 0-1000 m depth profiles of $\mathrm{Chl}$ and $b_{\mathrm{bp}}$ acquired by the global Biogeochemical-Argo (aka BGC-Argo) float array. $b_{\mathrm{bp}}^{\mathrm{k}}$ was demonstrated also to vary over depth and to account only for a small fraction of total $b_{\mathrm{bp}}$ in productive areas, while being the main source of $b_{\mathrm{bp}}$ in oligotrophic waters [25].

The former evidence suggests that if a realistic spatio-temporal variation of $b_{\mathrm{bp}}^{\mathrm{k}}$ is introduced in the $\mathrm{C}_{\text {phyto }}$ algorithm its precision and accuracy can be largely improved. Specifically, the hypothesis that $b_{\mathrm{bp}}^{\mathrm{k}}$ varies in space and time is here applied monthly at the scale of satellite pixel rather than using a unique $b_{\mathrm{bp}}^{\mathrm{k}}$ value or pre-defined bioregions. Algorithm outputs are validated against the only available, to the best of our knowledge, in situ dataset and compared to the performances of Beh05, Bel18, and Bre12 with single $b_{\mathrm{bp}}^{\mathrm{k}}$ values. The performance of the new algorithm is also compared to empirical approaches [14,16]. The analysis was developed globally by partitioning the data among Optical Water Class (OWC; [32]) to explore the efficiency and applicability of the different tested approaches.

\section{Data and Methods}

\subsection{Ocean Colour Data}

The full European Space Agency (ESA) Ocean Colour-Climate Change Initiative (OC-CCI) time series (1997-2019) of global daily $\mathrm{R}_{\mathrm{rs}}$ and Chl version 4.2 data at $4 \mathrm{~km}$ resolution was downloaded from the ESA OC-CCI FTP server (https://esa-oceancolour-cci.org; ftp://oceancolour.org/occci-v4.2/ geographic/netcdf/daily/rrs/). ESA OC-CCI data products are the result of the merging of SeaWiFS, MERIS, MODIS, and VIIRS observations in which the inter-sensor biases are removed. Version 4.2 includes the latest NASA reprocessing R2018.0, which mostly accounts for the ageing of the MODIS sensor. The ESA OC-CCI provides the daily $\mathrm{R}_{\mathrm{rs}}$ data and associated uncertainty maps in terms of bias and root mean square error. In this work, for each daily $\mathrm{R}_{\mathrm{rs}}$, the bias was also extracted and then corrected pixel-by-pixel, as recommended in the Product User Guide [33].

Chl was estimated with a blending of the OCI (as implemented by NASA, itself a combination of CI and OC4), OC5, and OC3 algorithms. For each daily Chl value, the bias was also extracted and compensated at the pixel scale. Daily $b_{\mathrm{bp}}$ maps at $443 \mathrm{~nm}$ were produced from daily $\mathrm{R}_{\mathrm{rs}}$ for the same period (1997-2019) by applying the Quasi-Analytical Algorithm (QAA; [34,35]) with prior correction for Raman scattering [27,36]. The accuracy of the QAA in retrieving $b_{\mathrm{bp}}$ was fully demonstrated [27,36-39]. In this work, the QAA algorithm was thus selected for its high efficiency in the $b_{\mathrm{bp}}$ retrievals, and to show consistency and coherency with the OC-CCI program in which the QAA is the designated algorithm $[37,40]$.

The daily datasets were then under-sampled to $25 \mathrm{~km}$ resolution to resolve only the broader oceanographic scales of variability.

\subsection{Computation of $b_{b p}^{k}$}

$b_{\mathrm{bp}}^{\mathrm{k}}$ was estimated for every pixel and month by using the following basic relationship $[7,25,27,28]$ :

$$
b_{\mathrm{bp}}^{\mathrm{k}}=b_{\mathrm{bp}}-k \cdot \mathrm{Chl}
$$

where $k$ is the slope of the least-square regression fit between daily $\mathrm{Chl}$ and $b_{\mathrm{bp}}$, and $b_{\mathrm{bp}}^{\mathrm{k}}$ is the intercept of the fit [7]. The term $k \cdot \mathrm{Chl}$ thus identifies the fraction of $b_{\mathrm{bp}}$ that covaries with Chl $[7,25,27,28]$. A scheme of the algorithm implementation is shown in Figure S1. 
We computed monthly climatological $b_{\mathrm{bp}}^{\mathrm{k}}$ maps at $25 \mathrm{~km}$ by applying Equation (2) to daily Chl and $b_{\mathrm{bp}}$ data within each month of the year from 1998 to 2019 . The estimation of $b_{\mathrm{bp}}^{\mathrm{k}}$, and consequently of $\mathrm{C}_{\text {phyto }}$, relies on good relationships between $\mathrm{Chl}$ and $b_{\mathrm{bp}}$ which then constitutes the fundamental condition to exploit this method. To this aim, for each $b_{\mathrm{bp}}^{\mathrm{k}}$ map, the significance $S$ (using Student's $t$-test), the Pearson correlation coefficient ( $r$; not shown), and the $1 \sigma$ uncertainty maps (due to the linear fit between $\mathrm{Chl}$ and $b_{\mathrm{bp}}$; see Section 15.2 of [41]) were computed to give an estimate of the robustness of the fit.

We then applied for each pixel of every resulting monthly $b_{\mathrm{bp}}^{\mathrm{k}}$ map an additional moving average of $1000 \mathrm{~km}$ to remove any source of noise and smaller scale variability, while conserving the large-scale oceanic patterns [42].

Finally, the monthly $b_{\mathrm{bp}}^{\mathrm{k}}$ maps computed with the new approach were interpolated to obtain daily climatological $b_{\mathrm{bp}}^{\mathrm{k}}$ maps at $25 \mathrm{~km}$ resolution. Daily pixel-based estimates were then used to assess $\mathrm{C}_{\text {phyto }}$ by applying a revised Equation $(1)[7,27,28]$, such as:

$$
\mathrm{C}_{\text {phyto }}=\left[b_{\mathrm{bp}}(443)-b_{\mathrm{bp}}^{\mathrm{k}}(443)\right] \cdot \mathrm{SF}
$$

In some pixels, $C_{\text {phyto }}$ may show values less of, or close to 0 . This occurred for pixels where the Chl- $b_{\mathrm{bp}}$ relationship had a significance $S<0.95$ and $r \leq 0$. In these pixels, $b_{\mathrm{bp}}^{\mathrm{k}}$ may be higher than $b_{\mathrm{bp}}$ thus giving non-reliable, negative estimations of $\mathrm{C}_{\text {phyto }}$ (less than 0; e.g., in the subtropical gyres). For these areas, we applied a threshold of $C_{\text {phyto }}$ equal to $0.13 \mathrm{mg} \mathrm{C} \mathrm{m}^{-3}$ to highlight that $C_{\text {phyto }}$ is expected to be low [14]. All match-up points falling in the areas where the Chl- $b_{\mathrm{bp}}$ relationship showed a significance $S<0.95$ and $r \leq 0$ were not included in the validation and algorithm performance analysis (Figure S1). These areas thus need to be interpreted and managed with caution.

For comparative purposes, $\mathrm{C}_{\text {phyto }}$ was also computed following the approaches of Beh05, Bel18, and Bre12 with single $b_{\mathrm{bp}}^{\mathrm{k}}$ values of $3.5 \cdot 10^{-4} \mathrm{~m}^{-1}, 9.5 \cdot 10^{-4} \mathrm{~m}^{-1}$, and $7.0 \cdot 10^{-4} \mathrm{~m}^{-1}$, respectively. In addition, the performance of the new algorithm was compared to the empirical algorithms of Martinez-Vicente et al. (2017; hereafter MV17; [14]) and Graff et al., (2015; hereafter Gra15; [16].

\subsection{In Situ Reference Data}

The in situ $\mathrm{C}_{\text {phyto }}$ database [14] is a compilation of data acquired from many sources (e.g., MAREDAT and Atlantic Meridional Transect, AMT, cruises) for a total of $\mathrm{N}=557$ data points and consists of carbon biomass of picophytoplankton organisms (i.e., cell size $<2 \mu \mathrm{m}$ ). It was downloaded from http://www.zenodo.org (doi:10.5281/zenodo.1067229). For complete details about the in situ dataset see [14]. Only pixels with a good $(S \geq 0.95$ and $r>0)$ satellite relationship between Chl and $b_{\mathrm{bp}}$ were retained so that the original 557 data points decreased to a total of 396 matchups (Figure 1). The final matchup database encompassed from oligotrophic to mesotrophic waters (Chl from 0.035 to $3.13 \mathrm{mg} \mathrm{m}^{-3}$ and $\mathrm{C}_{\text {phyto }}$ from 1.80 to $60.25 \mathrm{mg} \mathrm{C} \mathrm{m}^{-3}$ ) and OWC from 1 to 13 . OWC from 1 to 6 , corresponding to less productive waters, represented $56 \%$ of the in situ data.

\subsection{Statistical Assessment}

Estimated satellite $C_{\text {phyto }}\left(y_{i}\right)$ computed with Equation (3) was compared to reference in situ data $\left(x_{i}\right)$ by computing the bias $\left(\delta ; \mathrm{mg} \mathrm{m}^{-3}\right)$, the relative bias in percentage $(\nabla ;$ in $\%)$, and the standard deviation of the difference $\left(\sigma_{\Delta} ; \mathrm{mg} \mathrm{m}^{-3}\right)$. The assessment was made for each OWC individually and for all matchups at once:

$$
\begin{gathered}
\delta=\frac{1}{N} \sum_{i=1}^{N}\left(y_{i}-x_{i}\right) \\
\nabla=100 * \frac{1}{N} \sum_{i=1}^{N} \frac{\left(y_{i}-x_{i}\right)}{x_{i}}
\end{gathered}
$$




$$
\sigma_{\Delta}=\sqrt{\left.\frac{1}{N-1} \sum_{i=1}^{N}\left[\left(y_{i}-x_{i}\right)-\overline{\left(y_{i}-x_{i}\right.}\right)\right]^{2}}
$$
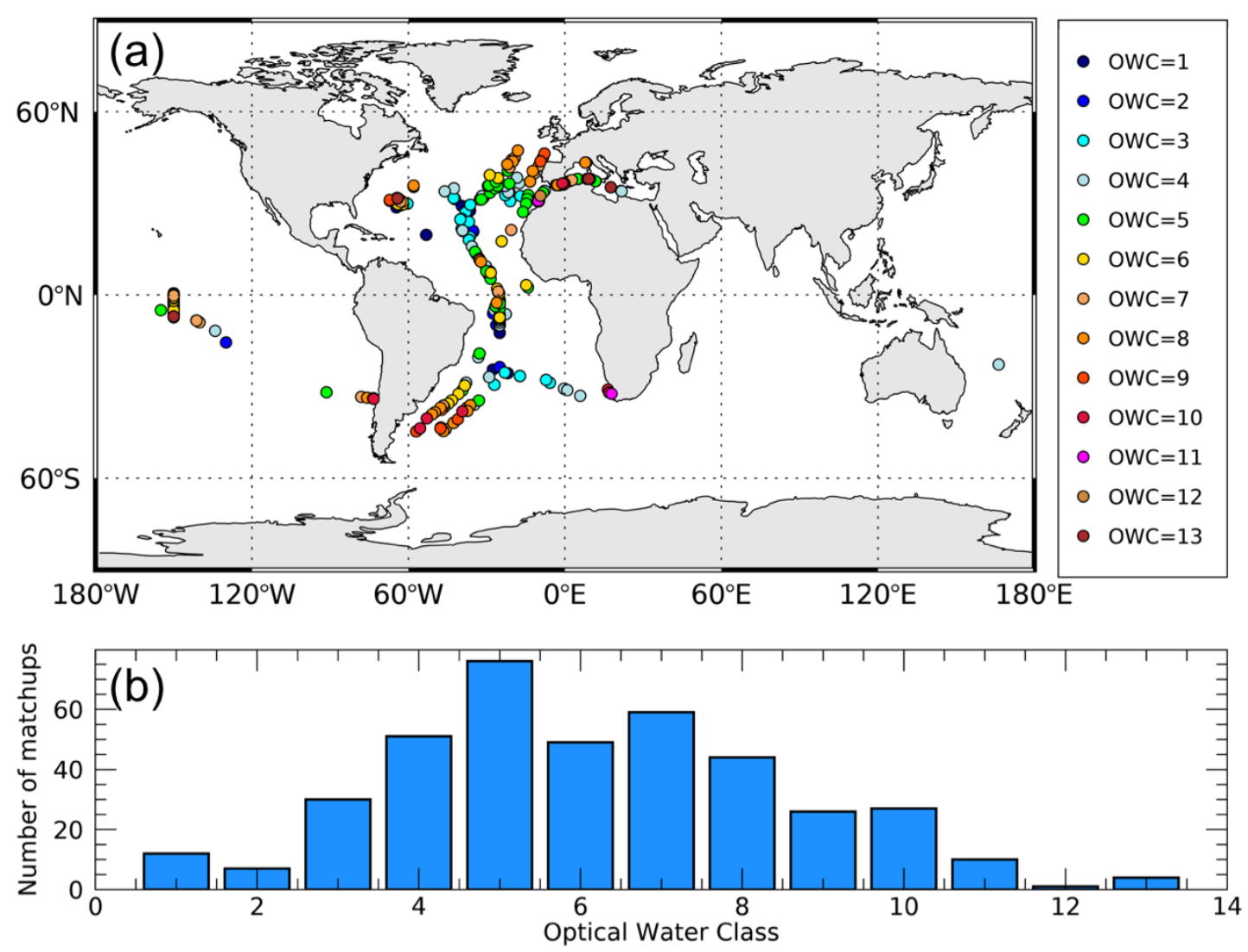

Figure 1. Geographical distribution of the matchup dataset $(\mathrm{N}=396)$ used for the analysis. Each datapoint is also associated with the specific Optical Water Class (OWC) (a). Number of matchups per OWC (b).

\section{Results}

\section{Algorithm Performance for $C_{\text {phyto }}$ Retrievals}

Results and statistics of the comparison between satellite $\mathrm{C}_{\text {phyto }}$ estimates obtained with our algorithm and the previously published values, and in situ $\mathrm{C}_{\text {phyto, }}$ are reported in Table 1 and Figure 2 . Overall, algorithms perform with $\nabla$ values spanning from $23.7 \%$ to $203 \%$. The algorithm here developed shows the smallest bias ( $\nabla$ of $23.7 \%$ ). By comparison, the algorithms based on a constant $b_{\mathrm{bp}}^{\mathrm{k}}$ value have lower performance, and Gra15, Beh05, and MV17 showed a systematic overestimation for low $\mathrm{C}_{\text {phyto }}$ values (Table 1 and Figure 2).

The $b_{\mathrm{bp}}$-based algorithms that use a single $b_{\mathrm{bp}}^{\mathrm{k}}$ constant value (Beh05, Bre12, and Bel18) show similar $\sigma_{\Delta}$. Specifically, Bre12 has a $b_{\mathrm{bp}}^{\mathrm{k}}$ value that is twice as high as that used in Beh05, and Bel18 has a value nearly three times larger than that of Beh05. $\nabla$ ranges from $23.7 \%$ (Bel18) and $80.1 \%$ (Bre12), to $130.3 \%$ (Beh05), resulting in different performance in relation to the selection of the single value. 
Table 1. Basic statistics for each single approach. For each approach is reported the bias $\left(\delta\right.$; in $\left.\mathrm{mg} \mathrm{m}^{-3}\right)$, the standard deviation $\left(\sigma_{\Delta}\right.$; in $\left.\mathrm{mg} \mathrm{m}^{-3}\right)$, and the relative percentage bias $(\nabla ;$ in \%). Note that OWCs 1 and 2 are grouped in a single class to increase the number of observations available for the statistics. This is also replicated for OWCs 11, 12, and 13. The statistics using $\log _{10}$ transformed data for all OWCs are reported in Table S1.

\begin{tabular}{|c|c|c|c|c|c|c|c|c|c|c|c|c|c|c|c|c|c|c|c|}
\hline \multirow{2}{*}{ OWCs } & \multirow{2}{*}{ N. obs. } & \multicolumn{3}{|c|}{ This Study } & \multicolumn{3}{|c|}{ Bel18 } & \multicolumn{3}{|c|}{ Gra15 } & \multicolumn{3}{|c|}{ Beh05 } & \multicolumn{3}{|c|}{ Bre12 } & \multicolumn{3}{|c|}{ MV17 } \\
\hline & & $\delta$ & $\sigma_{\Delta}$ & $\nabla$ & $\delta$ & $\sigma_{\Delta}$ & $\nabla$ & $\delta$ & $\sigma_{\Delta}$ & $\nabla$ & $\delta$ & $\sigma_{\Delta}$ & $\nabla$ & $\delta$ & $\sigma_{\Delta}$ & $\nabla$ & $\delta$ & $\sigma_{\Delta}$ & $\nabla$ \\
\hline $1: 2$ & 19 & -1.9 & 5.0 & 5.0 & -2.6 & 6.2 & 8.8 & 9.2 & 6.0 & 259.4 & 5.2 & 6.2 & 174.9 & 0.7 & 6.2 & 78.0 & 8.5 & 7.2 & 250.0 \\
\hline 3 & 30 & -1.8 & 3.4 & -13.9 & -2.8 & 3.4 & -27.3 & 9.1 & 3.3 & 211.8 & 5.0 & 3.4 & 129.8 & 0.5 & 3.4 & 38.2 & 7.9 & 3.9 & 189.2 \\
\hline 4 & 51 & -1.7 & 7.6 & 18.2 & -2.1 & 8.5 & 31.3 & 9.4 & 8.6 & 193.1 & 5.7 & 8.5 & 141.1 & 1.2 & 8.5 & 77.0 & 10.7 & 10.6 & 213.6 \\
\hline 5 & 76 & -1.6 & 6.6 & 8.1 & -3.2 & 7.9 & 5.9 & 8.2 & 7.7 & 122.8 & 4.6 & 7.9 & 85.8 & 0.03 & 7.9 & 39.2 & 9.4 & 9.2 & 142.6 \\
\hline 6 & 49 & 1.5 & 7.9 & 38.7 & -0.2 & 9.3 & 26.9 & 11.0 & 9.0 & 131.4 & 7.6 & 9.3 & 99.7 & 3.1 & 9.3 & 57.2 & 14.4 & 11.4 & 163.0 \\
\hline 7 & 59 & -1.9 & 8.4 & -0.4 & 0.2 & 9.5 & 13.7 & 11.3 & 9.0 & 102.9 & 8.0 & 9.5 & 76.0 & 3.5 & 9.5 & 39.7 & 15.2 & 12.4 & 132.3 \\
\hline 8 & 44 & -0.5 & 10.1 & 38.8 & 5.2 & 10.3 & 73.6 & 15.8 & 9.9 & 164.99 & 13.0 & 10.3 & 139.9 & 8.5 & 10.3 & 101.3 & 23.3 & 13.1 & 220.0 \\
\hline 10 & 27 & 4.6 & 16.5 & 103.4 & 17.2 & 17.6 & 206.2 & 26.7 & 17.0 & 278.2 & 25.0 & 17.6 & 266.2 & 20.4 & 17.6 & 231.2 & 41.1 & 22.6 & 396.0 \\
\hline $11: 13$ & 15 & 3.2 & 14.0 & 51.7 & 12.2 & 15.2 & 148.8 & 22.6 & 15.2 & 275.9 & 20.0 & 15.2 & 241.4 & 15.5 & 15.2 & 187.3 & 31.5 & 30.4 & 355.6 \\
\hline $1: 6$ & 225 & -1.0 & 6.8 & 14.0 & -2.2 & 7.9 & 12.0 & 9.3 & 7.7 & 164.0 & 5.6 & 7.9 & 114.7 & 1.1 & 7.9 & 54.8 & 10.7 & 9.6 & 178.4 \\
\hline $7: 13$ & 171 & 0.5 & 11.8 & 36.6 & 7.3 & 13.7 & 86.5 & 17.8 & 13.0 & 173.8 & 15.1 & 13.7 & 150.7 & 10.6 & 13.7 & 113.3 & 26.0 & 18.4 & 235.4 \\
\hline All & 396 & -0.4 & 9.2 & 23.7 & 1.9 & 11.8 & 44.2 & 13.0 & 11.1 & 168.2 & 9.7 & 11.8 & 130.3 & 5.2 & 11.8 & 80.1 & 17.3 & 16.0 & 203.0 \\
\hline
\end{tabular}




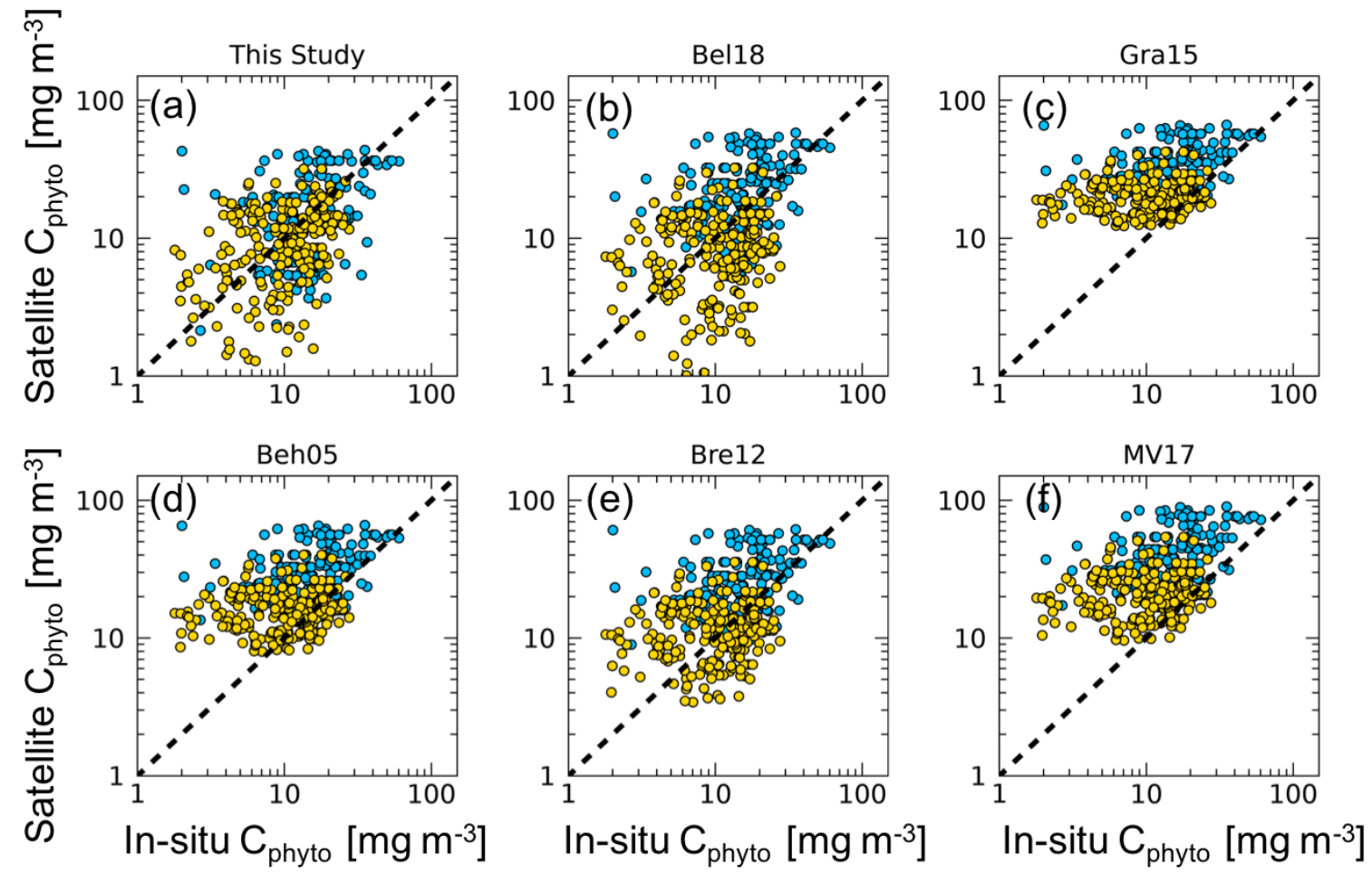

Figure 2. Matchups between satellite $C_{\text {phyto }}$ versus in situ $C_{\text {phyto }}$ data for each algorithm $(N=396)$. The dashed line represents the 1:1 ratio. Gold dots represent in situ $C_{\text {phyto }}$ data corresponding to OWCs 1-6; blue dots represent in situ $C_{\text {phyto }}$ data for OWCs 7-13. Statistics are reported in Table 1.

In the case of Beh05, a source of discrepancy leading to such a bias may be linked to the $b_{\mathrm{bp}}$ input from the algorithm as also highlighted in [27]. Indeed, the original equation was derived using the GSM algorithm [29] for obtaining a relationship between Chl and $b_{\mathrm{bp}}$ and thus for the $b_{\mathrm{bp}}^{\mathrm{k}}$ estimation, instead of the QAA, applied here. In addition, it has recently been found that Raman scattering (here corrected prior to the QAA application) plays a fundamental role for the retrievals of $b_{\mathrm{bp}}$ in very clear waters because, if not corrected, it results in overestimation of $b_{\mathrm{bp}}[36,43]$.

However, these results highlight how the use of a single $b_{\mathrm{bp}}^{\mathrm{k}}$ determines a strong overestimation of satellite $C_{\text {phyto, }}$ in line with the results of MV17 (Table 1 and Figure 2). The comparison between our approach and previously published models underlines the necessity to account for the spatio-temporal variability of the $b_{\mathrm{bp}}^{\mathrm{k}}$ for satellite-based $\mathrm{C}_{\text {phyto }}$ calculation. However, because Bre12 and Bel18 show relatively low bias, such approaches might be used alternatively to the new approach proposed here because it may occur in the most oligotrophic waters (e.g., subtropical gyre areas). Note that in Bre12, the $b_{\mathrm{bp}}^{\mathrm{k}}$ was at $470 \mathrm{~nm}$ so that the overestimation of $C_{\text {phyto }}$ can decrease if the $b_{\mathrm{bp}}^{\mathrm{k}}$ is reported to the band of $443 \mathrm{~nm}$.

The empirical algorithms of Gra15 and MV17 yield the worst results in terms of $\nabla$. In the case of Gra15, this is the consequence of the few in situ measurements used for the algorithm definition, located in the Equatorial Pacific Ocean and in the Atlantic Ocean. Extrapolation of their algorithm, developed at $470 \mathrm{~nm}$, to $443 \mathrm{~nm}$, may also have had an effect. Regarding MV17, the results found are consistent with those reported in Tables 3 and 5 of their work.

MV17 reported that the geographical distribution of the in situ data, the median $\mathrm{C}_{\text {phyto }}$ concentrations, and the carbon-to-chlorophyll ratios are in agreement with previous observations in oligotrophic oceanic conditions $[16,18]$. The fact that the in situ $\mathrm{C}_{\text {phyto }}$ dataset used here contains only data from the picophytoplankton population must be taken into account for the interpretation of the algorithm evaluation. In most oligotrophic waters (OWCs from 1 to 6 ), $\delta$ shows the lowest values for all of the algorithms, with a maximum value of $14.4 \mathrm{mg} \mathrm{m}^{-3}$ (Table 1). However, when analyzing the $\nabla$ 
index, the $\mathrm{C}_{\text {phyto }}$ computed by considering the spatio-temporal variability of $b_{\mathrm{bp}}^{\mathrm{k}}$ is the most efficient (Table 1), with the exception of OWCs 5 and 6, for which Bel18 shows the best performance. Indeed, within OWCs in which picophytoplankton is expected to dominate (OWCs from 1 to 6 ), the performance of the majority of the tested algorithms generally improves (Table 1), with the exceptions of Gra15 and MV17. As expected, there is a decrease in the accuracy for all of the algorithms in the OWCs from 7 to 13. This could be influenced by the dominance of nano- and micro-phytoplankton (cell size $>2 \mu \mathrm{m}$ ) in these waters, whereas the picophytoplankton contribute in low relative proportions [14]. Because most of the $b_{\mathrm{bp}}$ signal is due to particles with equivalent diameters larger than that those associated with picophytoplankton [23], a decreasing performance of the $b_{\mathrm{bp}}$-based algorithms in water dominated by larger cells (e.g., nano- and micro-phytoplankton) was expected (Table 1).

\section{Discussion}

\subsection{Spatial and Temporal Distribution of $C_{\text {phyto }}$}

The global mean climatology of $C_{\text {phyto }}$ (Figure 3a) agrees with the expected geographical distribution [14]. $\mathrm{C}_{\text {phyto }}$ highs are found in the most productive regions such as the high latitude regions and coastal areas, and in upwelling systems such as those off Mauritania and Perù, the Benguela and Kuroshio currents, and along the equatorial belt of the Pacific Ocean (Figure 3a). $\mathrm{C}_{\text {phyto }}$ lows are found in mid-latitude areas such as the subtropical gyres or the Eastern Mediterranean Sea and Black Sea. $C_{\text {phyto }}$ varies within the same order of magnitude of recent estimates made using satellite data [14] and biogeochemical models [44]. The two main oceanic regimes as defined by [45] are also highlighted from our analysis: "photoacclimation-dominance" and "biomass-dominance". The former is typical of oligotrophic areas (e.g., subtropical gyres) where the variability of Chl is uncoupled from biomass and the process of acclimation to light and nutrients drives $\mathrm{Chl}$ variations [45]. In these areas, $\mathrm{C}_{\text {phyto }}$ shows the lowest mean values $\left(<10 \mathrm{mg} \mathrm{C} \mathrm{m}^{-3}\right)$. Conversely, the latter is typical of most productive areas where $\mathrm{Chl}$ and $\mathrm{b}_{\mathrm{bp}}$ strongly covary $[31,46]$. The high $\mathrm{Chl}-\mathrm{b}_{\mathrm{bp}}$ co-variability indicates that particles (and biomass) co-vary with phytoplankton abundance, whereas the physiological photoacclimation process plays a secondary role in determining the Chl variations; e.g., in the North Atlantic and Southern Oceans, $\mathrm{C}_{\text {phyto }}$ shows the highest mean values $\left(>30 \mathrm{mg} \mathrm{C} \mathrm{m}^{-3}\right)$.

The amplitude of seasonal variations (i.e., interannual variability) of $C_{\text {phyto }}$ is shown in Figure $3 b$. Most of the variability is observed at high latitudes (e.g., Baltic Sea, Irish Sea, Norwegian Sea, North Sea), in the North Pacific and North Atlantic Oceans, and in the Southern Ocean, because $\sigma_{\text {std }}$ values are higher than $12 \mathrm{mg} \mathrm{m}^{-3}$. The North Atlantic and Southern Oceans are characterized by high seasonal variations due to intense productive months followed by unproductive periods [47-49] (Figures S2-S13). In the North Atlantic Ocean, $\mathrm{C}_{\text {phyto }}$ starts to increase in May, reaching the maximum values in June and July (>50 $\mathrm{mg} \mathrm{C} \mathrm{m}^{-3}$ ) following the spring bloom. Then, $\mathrm{C}_{\text {phyto }}$ decreases to the lowest values for the remainder of the year [47]. In the Southern Ocean, $\mathrm{C}_{\text {phyto }}$ follows the typical seasonal cycle with high values during the most productive months which occur from November to March $\left(>50 \mathrm{mg} \mathrm{C} \mathrm{m}^{-3}\right)$. Highs are mostly observed in the Antarctic Circumpolar Current (ACC) and the Patagonia Shelf. Later, there is a decrease in $\mathrm{C}_{\text {phyto }}$ from May to September (Figures S2-S13). Additionally, the northwestern Indian Ocean, known to be an Oxygen Minimum Zone, as well as the Benguela upwelling system, also show significant variability in $\mathrm{C}_{\text {phyto, }}$ with $\sigma_{\text {std }}$ greater than $12 \mathrm{mg} \mathrm{m}^{-3}$. Conversely, mid-latitude areas (e.g., in the subtropical gyres), display much lower variability, with $\sigma_{\text {std }}$ less than $2 \mathrm{mg} \mathrm{C} \mathrm{m}^{-3}$.

Figure S14 clearly shows how the single $b_{b p}^{k}$ of Beh05 is located at the lowest limit of possible values, confirming that reported in [28], whereas the Bel18 and Bre12 single values are representative of a wider area. In the subtropical gyres, $b_{b p}^{k}$ does not significantly deviate from the coefficient found by Beh05, but in the most productive regions (e.g., North Atlantic and Southern Oceans, high latitude seas, and coastal upwelling regions), they largely differ with great impact on $\mathrm{C}_{\text {phyto }}$ estimations. This discrepancy in $\mathrm{C}_{\text {phyto }}$ is still valid in the case of the use of Bel18 and Bre12 single values, but for other areas (e.g., in the subtropical gyres or in the Mediterranean Sea), the use of the single value of Bel18 
or Bre12 yields an underestimation of $C_{\text {phyto, }}$, whereas in the productive Arctic and Southern Oceans $\mathrm{C}_{\text {phyto }}$ is generally overestimated. This is also indicated in the seasonal $b_{b p}^{k}$ variation as reported in the Figures S2-S13. In the North Atlantic Ocean, $b_{b p}^{k}$ shows high values during the spring bloom and low values from December to April. However, in this area, the $b_{b p}^{k}$ is only a small fraction of the entire $b_{\mathrm{bp}}$ signal as the consequence of the high variability in the $b_{b p}$ and phytoplankton abundance $[25,27]$ thus following the phytoplankton dynamics. In the Southern Ocean, and especially the region influenced by the ACC and Patagonia Shelf, $b_{b p}^{k}$ shows highs from December to April (i.e., due to coccoliths) and lows in the period May-September in accordance also with the $\mathrm{C}_{\text {phyto }}$ seasonal cycle [25]. In less productive seas, the seasonal cycle of $b_{b p}^{k}$ is smooth, suggesting low NAP variations. In these areas, the seasonal $b_{b p}^{k}$ change is weak throughout the year but also dominates the $b_{\mathrm{bp}}$ signal [25]. These areas are characterized by limited nutrient availability determining low $\mathrm{C}_{\text {phyto }}$, mostly of picophytoplankton class, high bacterial, and detrital concentrations [50-52]. It follows that the use of a varying $b_{b p}^{k}$ enables accounting for its seasonal variations in the $C_{\text {phyto }}$ computation, giving the model more flexibility in relation to the change of the biogeochemical and trophic conditions.
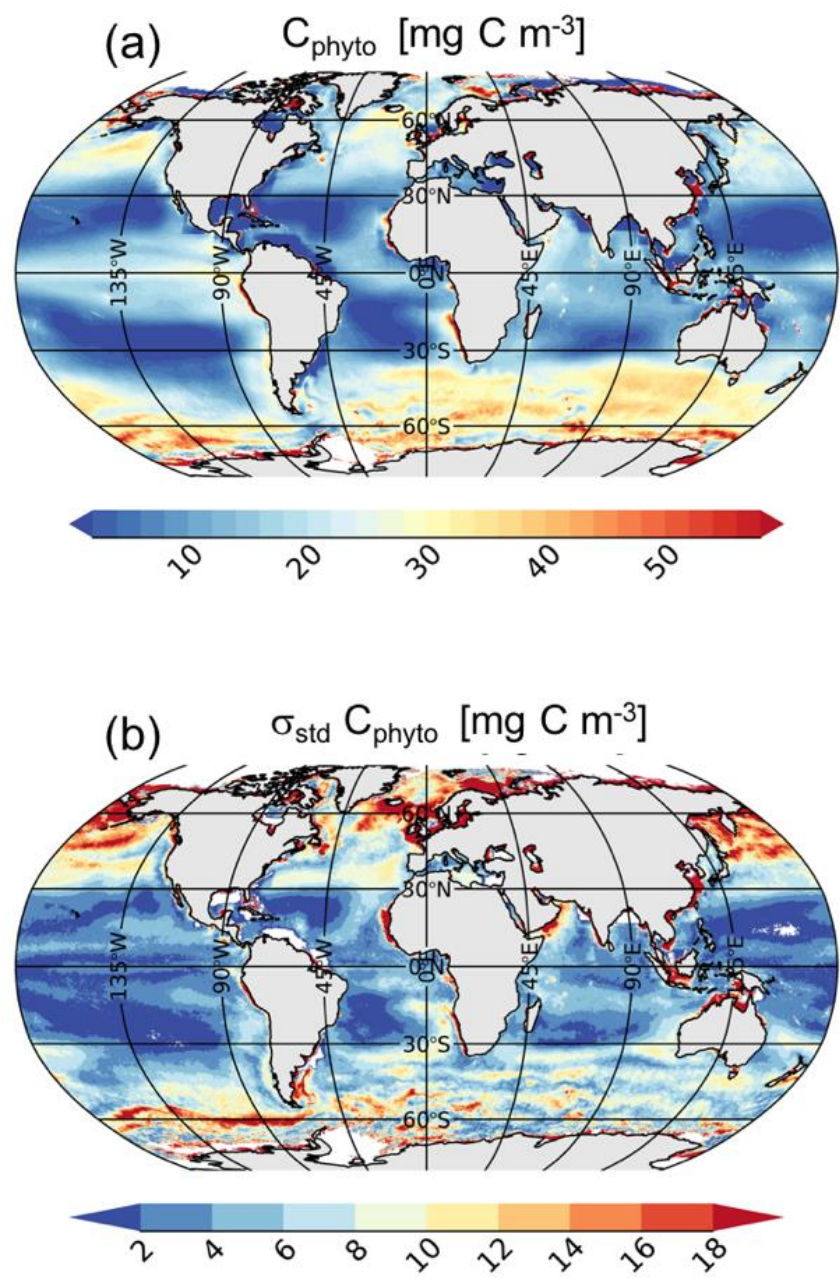

Figure 3. Annual global mean (a) and standard deviation (b) of $C_{\text {phyto }}$. Note that at high latitudes the number of satellite observations used for the mean and standard deviation computations are lower than those used at low or mid-latitudes due to the winter darkness (i.e., high sun zenith angle).

\subsection{Caveats of the $C_{\text {phyto }}$ Algorithm}

Three main caveats of the algorithm should be noted. The first is that $\mathrm{C}_{\text {phyto }}$ assumes a constant scaling factor, SF, equal to $13,000 \mathrm{mg} \mathrm{C} \mathrm{m}^{-2}$, following [7]. This can be an additional possible source of 
error in the satellite retrievals of $C_{\text {phyto }}$. Therefore, one important future effort should be to investigate a refined scaling factor relating $b_{\mathrm{bp}}$ to $C_{\text {phyto }}$ coupled with the $b_{\mathrm{bp}}^{\mathrm{k}}$ space-time variability as presented in this work. With this perspective, additional laboratory work should be done to evaluate if change in $\mathrm{SF}$ values can affect the $\mathrm{C}_{\text {phyto }}$ estimations.

The second caveat of the algorithm is that it relies on a tight relationship between $b_{\mathrm{bp}}$ and $\mathrm{Chl}$, which is influenced by the algorithms (including the atmospheric correction) used for Chl and $b_{\mathrm{bp}}$ retrievals, in addition to the environmental conditions. In some areas of the subtropical gyres, the Chl- $b_{\mathrm{bp}}$ relationship showed $S<0.95$ (Figures S2-S13) and $r$ smaller than or close to 0 , as also reported by [28]. The main reason for this relationship may be the photoacclimation process, known to be dominant in such areas over the year, and which introduces variability in Chl that is unrelated to biomass. In these areas, our refined method must be applied with caution. With this perspective, one future challenge is to solve this limitation in $b_{\mathrm{bp}}^{\mathrm{k}}$ computation and, consequently, in the satellite $\mathrm{C}_{\text {phyto }}$. Indeed, as the subtropical gyres cover about $60 \%$ of the global ocean, it can be of a great importance to compute $\mathrm{C}_{\text {phyto }}$ and $\mathrm{Chl}: \mathrm{C}_{\text {phyto }}$ to understand oceanic biogeochemical cycles. Conversely, the remaining areas of global ocean (e.g., the North Atlantic Ocean) present significant positive $r$ and highly significant $S$ (Figures S2-S13) throughout the year, indicating that either $b_{\mathrm{bp}}$ or Chl can be used for determining the phytoplankton dynamics and distribution, as expected in open-ocean waters [27]. In these areas, the algorithm performance is robust.

The third caveat is that the algorithm validation is restricted only to in situ $\mathrm{C}_{\text {phyto }}$ data associated with picophytoplankton carbon. It determines that the algorithm performance has to be interpreted with caution in those areas where other phytoplankton size classes dominate. This means that, currently, it is not possible to define the accuracy for OWCs from 7 to 13. Indeed, Table 1 shows that there is a decrease in the accuracy for all of the algorithms in the OWCs where nano- and micro-phytoplankton dominates. Thus, one future need is to improve the in situ $C_{\text {phyto }}$ dataset with new measurements representative of all of the phytoplankton size classes.

\section{Conclusions and Future Perspectives}

In this work, a revisited version of the original $b_{\mathrm{bp}}$-based algorithm for $\mathrm{C}_{\text {phyto }}$ retrieval from space [7] was proposed. The spatio-temporal variations of the background backscattering coefficient of non-algal particles $\left(b_{\mathrm{bp}}^{\mathrm{k}}\right)$ is the crucial part of this refinement, and builds upon a series of recent studies $[25,27,28]$. The main findings are:

1. The new $\mathrm{C}_{\text {phyto }}$ algorithm proposed here performs better than any previously published model, with a relative error of $24 \%$ (Table 1 and Figure 2) with respect to a reference in situ dataset.

2. The new algorithm shows the lowest error in $\mathrm{C}_{\text {phyto }}(14.0 \%)$ across most of the OWCs in which the picophytoplankton population dominates (Table 1). On the contrary, the highest errors (36.6\%) occur in OWCs 7-13 in which larger phytoplankton cells are supposed to dominate (Table 1).

However, we acknowledge that the refined algorithm presented here could be improved by addressing the caveats mentioned above. Enlarging the databases of quality-controlled and freely accessible in situ $\mathrm{C}_{\text {phyto }}$ at the different size-classes (pico-, nano-, and micro-), measured simultaneously with an array of optical variables (particularly $b_{\mathrm{bp}}$ ) could help to reduce uncertainties in $\mathrm{C}_{\text {phyto }}$ retrieval from space. Improving the accuracy of satellite $C_{\text {phyto }}$ could be of great importance to adding new knowledge regarding the contribution of phytoplankton to particulate organic carbon, and for the validation of ocean primary productivity and biogeochemical models at a wider scale $[8,12]$.

Supplementary Materials: The following are available online at http://www.mdpi.com/2072-4292/12/21/3640/s1, Figure S1: Scheme of the algorithm developed, Table S1: Basic statistics of the validation analysis for all the matchup with $\log _{10}$ transformed data: Figures S2-S13: global monthly climatologies of $b_{\mathrm{bp}}^{\mathrm{k}}(\mathrm{a}), 1-\sigma$ uncertainty $(\mathrm{b})$, significance $\mathrm{S}(\mathrm{c})$ and $\mathrm{C}_{\text {phyto }}(\mathrm{d})$; Figure S14: global mean and standard deviation $b_{\mathrm{bp}}^{\mathrm{k}}$ maps. 
Author Contributions: Conceptualization, M.B., J.P., V.M.-V. and S.M.; Methodology, M.B., J.P., E.O. and S.M.; Data curation, M.B., S.M., J.P.; Writing-review and editing, all authors contributed equally. All authors have read and agreed to the published version of the manuscript.

Funding: M. Bellacicco has a postdoctoral fellowship by the European Space Agency (ESA). This work was supported by the ESA Living Planet Fellowship Project PHYSIOGLOB: Assessing the inter-annual physiological response of phytoplankton to global warming using long-term satellite observations, 2018-2020. Jaime Pitarch is supported by the Copernicus Climate Change Service contract: Independent Assessment of ECVs (C3S_511).

Acknowledgments: We thank ESA OC-CCI for providing publicly available ocean colour data (https://esaoceancolour-cci.org). Giorgio Dall'Olmo (PML), Rosalia Santoleri (CNR-ISMAR), Vittorio Brando (CNR-ISMAR) and Marie-Hélène Rio (ESA) are thanked for all the inputs, suggestions and discussion done since the early version of the manuscript. We wish to thank the four anonymous reviewers for their criticisms and suggestions that helped the manuscript to be improved.

Conflicts of Interest: The authors declare no conflict of interest.

\section{References}

1. Siegel, D.A.; Buesseler, K.O.; Doney, S.C.; Sailley, S.F.; Behrenfeld, M.J.; Boyd, P.W. Global assessment of ocean carbon export by combining satellite observations and food-web models. Glob. Biogeochem. Cycles 2014, 28, 181-196. [CrossRef]

2. Boyce, D.G.; Lewis, M.R.; Worm, B. Global phytoplankton decline over the past century. Nature 2010, 466, 591-596. [CrossRef] [PubMed]

3. Dutkiewicz, S.; Hickman, A.E.; Jahn, O.; Henson, S.; Beaulieu, C.; Monier, E. Ocean colour signature of climate change. Nat. Commun. 2019, 10, 578. [CrossRef] [PubMed]

4. O'Reilly, J.E.; Werdell, P.J. Chlorophyll algorithms for ocean color sensors-OC4, OC5 \& OC6. Remote Sens. Environ. 2019, 229, 32-47. [CrossRef]

5. Laws, E.A.; Bannister, T.T. Nutrient- and light-limited growth of Thalassiosira fluviatilis in continuous culture, with implications for phytoplankton growth in the ocean1. Limnol. Oceanogr. 1980, 25, 457-473. [CrossRef]

6. Behrenfeld, M.J.; Boss, E.S. Resurrecting the Ecological Underpinnings of Ocean Plankton Blooms. Annu. Rev. Mar. Sci. 2014, 6, 167-194. [CrossRef] [PubMed]

7. Behrenfeld, M.J.; Boss, E.; Siegel, D.A.; Shea, D.M. Carbon-based ocean productivity and phytoplankton physiology from space. Glob. Biogeochem. Cycles 2005, 19. [CrossRef]

8. Westberry, T.; Behrenfeld, M.J.; Siegel, D.A.; Boss, E. Carbon-based primary productivity modeling with vertically resolved photoacclimation. Glob. Biogeochem. Cycles 2008, 22. [CrossRef]

9. Behrenfeld, M.J.; Halsey, K.H.; Milligan, A.J. Evolved physiological responses of phytoplankton to their integrated growth environment. Philos. Trans. R. Soc. B Biol. Sci. 2008, 363, 2687-2703. [CrossRef] [PubMed]

10. Zhai, L.; Platt, T.; Tang, C.; Dowd, M.; Sathyendranath, S.; Forget, M.-H. Estimation of phytoplankton loss rate by remote sensing. Geophys. Res. Lett. 2008, 35. [CrossRef]

11. Zhai, L.; Platt, T.; Tang, C.; Sathyendranath, S.; Fuentes-Yaco, C.; Devred, E.; Wu, Y. Seasonal and geographic variations in phytoplankton losses from the mixed layer on the Northwest Atlantic Shelf. J. Mar. Syst. 2010, 80, 36-46. [CrossRef]

12. Dutkiewicz, S.; Hickman, A.E.; Jahn, O.; Gregg, W.W.; Mouw, C.B.; Follows, M.J. Capturing optically important constituents and properties in a marine biogeochemical and ecosystem model. Biogeosciences 2015, 12, 4447-4481. [CrossRef]

13. Fossum, K.N.; Ovadnevaite, J.; Ceburnis, D.; Dall'Osto, M.; Marullo, S.; Bellacicco, M.; Simó, R.; Liu, D.; Flynn, M.; Zuend, A.; et al. Summertime Primary and Secondary Contributions to Southern Ocean Cloud Condensation Nuclei. Sci. Rep. 2018, 8, 13844. [CrossRef]

14. Martínez-Vicente, V.; Evers-King, H.; Roy, S.; Kostadinov, T.S.; Tarran, G.A.; Graff, J.R.; Brewin, R.J.W.; Dall'Olmo, G.; Jackson, T.; Hickman, A.E.; et al. Intercomparison of Ocean Color Algorithms for Picophytoplankton Carbon in the Ocean. Front. Mar. Sci. 2017, 4. [CrossRef]

15. Martínez-Vicente, V.; Dall'Olmo, G.; Tarran, G.; Boss, E.; Sathyendranath, S. Optical backscattering is correlated with phytoplankton carbon across the Atlantic Ocean. Geophys. Res. Lett. 2013, 40, 1154-1158. [CrossRef] 
16. Graff, J.R.; Westberry, T.K.; Milligan, A.J.; Brown, M.B.; Dall'Olmo, G.; Dongen-Vogels, V.V.; Reifel, K.M.; Behrenfeld, M.J. Analytical phytoplankton carbon measurements spanning diverse ecosystems. Deep Sea Res. Part I Oceanogr. Res. Pap. 2015, 102, 16-25. [CrossRef]

17. Sathyendranath, S.; Stuart, V.; Nair, A.; Oka, K.; Nakane, T.; Bouman, H.; Forget, M.H.; Maass, H.; Platt, T. Carbon-to-chlorophyll ratio and growth rate of phytoplankton in the sea. Mar. Ecol. Prog. Ser. 2009, 383, 73-84. [CrossRef]

18. Marañón, E.; Cermeño, P.; Huete-Ortega, M.; López-Sandoval, D.C.; Mouriño-Carballido, B.; Rodríguez-Ramos, T. Resource Supply Overrides Temperature as a Controlling Factor of Marine Phytoplankton Growth. PLoS ONE 2014, 9, e99312. [CrossRef]

19. Kostadinov, T.S.; Siegel, D.A.; Maritorena, S. Retrieval of the particle size distribution from satellite ocean color observations. J. Geophys. Res. Ocean. 2009, 114. [CrossRef]

20. Kostadinov, T.S.; Milutinović, S.; Marinov, I.; Cabré, A. Carbon-based phytoplankton size classes retrieved via ocean color estimates of the particle size distribution. Ocean Sci. 2016, 12, 561-575. [CrossRef]

21. Roy, S.; Sathyendranath, S.; Platt, T. Size-partitioned phytoplankton carbon and carbon-to-chlorophyll ratio from ocean colour by an absorption-based bio-optical algorithm. Remote Sens. Environ. 2017, 194, 177-189. [CrossRef]

22. Stramski, D.; Boss, E.; Bogucki, D.; Voss, K.J. The role of seawater constituents in light backscattering in the ocean. Prog. Oceanogr. 2004, 61, 27-56. [CrossRef]

23. Organelli, E.; Dall'Olmo, G.; Brewin, R.J.W.; Tarran, G.A.; Boss, E.; Bricaud, A. The open-ocean missing backscattering is in the structural complexity of particles. Nat. Commun. 2018, 9, 5439. [CrossRef] [PubMed]

24. Zhang, X.; Hu, L.; Xiong, Y.; Huot, Y.; Gray, D. Experimental Estimates of Optical Backscattering Associated with Submicron Particles in Clear Oceanic Waters. Geophys. Res. Lett. 2020, 47, e2020GL087100. [CrossRef]

25. Bellacicco, M.; Cornec, M.; Organelli, E.; Brewin, R.J.W.; Neukermans, G.; Volpe, G.; Barbieux, M.; Poteau, A.; Schmechtig, C.; D'Ortenzio, F.; et al. Global Variability of Optical Backscattering by Non-algal particles From a Biogeochemical-Argo Data Set. Geophys. Res. Lett. 2019, 46, 9767-9776. [CrossRef]

26. Brewin, R.J.W.; Dall'Olmo, G.; Sathyendranath, S.; Hardman-Mountford, N.J. Particle backscattering as a function of chlorophyll and phytoplankton size structure in the open-ocean. Opt. Express 2012, 20, 17632-17652. [CrossRef]

27. Bellacicco, M.; Volpe, G.; Colella, S.; Pitarch, J.; Santoleri, R. Influence of photoacclimation on the phytoplankton seasonal cycle in the Mediterranean Sea as seen by satellite. Remote Sens. Environ. 2016, 184, 595-604. [CrossRef]

28. Bellacicco, M.; Volpe, G.; Briggs, N.; Brando, V.; Pitarch, J.; Landolfi, A.; Colella, S.; Marullo, S.; Santoleri, R. Global Distribution of Non-algal Particles from Ocean Color Data and Implications for Phytoplankton Biomass Detection. Geophys. Res. Lett. 2018, 45, 7672-7682. [CrossRef]

29. Garver, S.A.; Siegel, D.A. Inherent optical property inversion of ocean color spectra and its biogeochemical interpretation: 1. Time series from the Sargasso Sea. J. Geophys. Res. Ocean. 1997, 102, 18607-18625. [CrossRef]

30. Dall'Olmo, G.; Westberry, T.K.; Behrenfeld, M.J.; Boss, E.; Slade, W.H. Significant contribution of large particles to optical backscattering in the open ocean. Biogeosciences 2009, 6, 947-967. [CrossRef]

31. Dall'Olmo, G.; Boss, E.; Behrenfeld, M.; Westberry, T. Particulate optical scattering coefficients along an Atlantic Meridional Transect. Opt. Express 2012, 20, 21532-21551. [CrossRef] [PubMed]

32. Jackson, T.; Sathyendranath, S.; Mélin, F. An improved optical classification scheme for the Ocean Colour Essential Climate Variable and its applications. Remote Sens. Environ. 2017, 203, 152-161. [CrossRef]

33. Jackson, T.; Chuprin, A.; Sathyendranath, S.; Grant, M.; Zühlke, M.; Dingle, J.; Storm, T.; Boettcher, M.; Fomferra, N. Ocean Colour Climate Change Initiative (OC_CCI)—Interim Phase. Product User Guide. D3.4 PUG. 2019. Available online: https:/esa-oceancolour-cci.org/sites/esa-oceancolour-cci.org/alfresco.php?file= a68aa514-3668-4935-9235-fca10f7e8bee\&name=OC-CCI-PUG-v4.1-v1.pdf (accessed on 22 December 2019).

34. Lee, Z.; Carder, K.L.; Arnone, R.A. Deriving inherent optical properties from water color: A multiband quasi-analytical algorithm for optically deep waters. Appl. Opt. 2002, 41, 5755-5772. [CrossRef]

35. Lee, Z. Update of the Quasi-Analytical Algorithm (QAA_v6). Available online: http://www.ioccg.org/groups/ Software_OCA/QAA_v6_2014209.pdf (accessed on 22 December 2019). 
36. Pitarch, J.; Bellacicco, M.; Organelli, E.; Volpe, G.; Colella, S.; Vellucci, V.; Marullo, S. Retrieval of Particulate Backscattering Using Field and Satellite Radiometry: Assessment of the QAA Algorithm. Remote Sens. 2020, 12, 77. [CrossRef]

37. Brewin, R.J.W.; Sathyendranath, S.; Müller, D.; Brockmann, C.; Deschamps, P.-Y.; Devred, E.; Doerffer, R.; Fomferra, N.; Franz, B.; Grant, M.; et al. The Ocean Colour Climate Change Initiative: III. A round-robin comparison on in-water bio-optical algorithms. Remote Sens. Environ. 2015, 162, 271-294. [CrossRef]

38. Mélin, F.; Berthon, J.-F.; Zibordi, G. Assessment of apparent and inherent optical properties derived from SeaWiFS with field data. Remote Sens. Environ. 2005, 97, 540-553. [CrossRef]

39. Melin, F.; Zibordi, G.; Berthon, J. Uncertainties in Remote Sensing Reflectance from MODIS-Terra. IEEE Geosci. Remote Sens. Lett. 2012, 9, 432-436. [CrossRef]

40. Sathyendranath, S.; Brewin, R.J.W.; Brockmann, C.; Brotas, V.; Calton, B.; Chuprin, A.; Cipollini, P.; Couto, A.B.; Dingle, J.; Doerffer, R.; et al. An Ocean-Colour Time Series for Use in Climate Studies: The Experience of the Ocean-Colour Climate Change Initiative (OC-CCI). Sensors 2019, 19, 4285. [CrossRef]

41. Press, W.H.; Teukolsky, S.A.; Vetterling, W.T.; Flannery, B.P. Numerical Recipes in C; Cambridge University Press: Cambridge, UK, 1988.

42. Resplandy, L.; Lévy, M.; McGillicuddy, D.J., Jr. Effects of Eddy-Driven Subduction on Ocean Biological Carbon Pump. Glob. Biogeochem. Cycles 2019, 33, 1071-1084. [CrossRef]

43. Westberry, T.K.; Boss, E.; Lee, Z. Influence of Raman scattering on ocean color inversion models. Appl. Opt. 2013, 52, 5552-5561. [CrossRef]

44. Arteaga, L.; Pahlow, M.; Oschlies, A. Modeled Chl:C ratio and derived estimates of phytoplankton carbon biomass and its contribution to total particulate organic carbon in the global surface ocean. Glob. Biogeochem. Cycles 2016, 30, 1791-1810. [CrossRef]

45. Siegel, D.A.; Maritorena, S.; Nelson, N.B.; Behrenfeld, M.J. Independence and interdependencies among global ocean color properties: Reassessing the bio-optical assumption. J. Geophys. Res. Ocean. 2005, 110. [CrossRef]

46. Westberry, T.K.; Dall'Olmo, G.; Boss, E.; Behrenfeld, M.J.; Moutin, T. Coherence of particulate beam attenuation and backscattering coefficients in diverse open ocean environments. Opt. Express 2010, 18, 15419-15425. [CrossRef]

47. Westberry, T.K.; Schultz, P.; Behrenfeld, M.J.; Dunne, J.P.; Hiscock, M.R.; Maritorena, S.; Sarmiento, J.L.; Siegel, D.A. Annual cycles of phytoplankton biomass in the subarctic Atlantic and Pacific Ocean. Glob. Biogeochem. Cycles 2016, 30, 175-190. [CrossRef]

48. Balch, W.M. The Ecology, Biogeochemistry, and Optical Properties of Coccolithophores. Annu. Rev. Mar. Sci. 2018, 10, 71-98. [CrossRef]

49. Barbieux, M.; Uitz, J.; Bricaud, A.; Organelli, E.; Poteau, A.; Schmechtig, C.; Gentili, B.; Obolensky, G.; Leymarie, E.; Penkerc'h, C.; et al. Assessing the Variability in the Relationship between the Particulate Backscattering Coefficient and the Chlorophyll a Concentration from a Global Biogeochemical-Argo Database. J. Geophys. Res. Ocean. 2018, 123, 1229-1250. [CrossRef]

50. Heywood, J.L.; Zubkov, M.V.; Tarran, G.A.; Fuchs, B.M.; Holligan, P.M. Prokaryoplankton standing stocks in oligotrophic gyre and equatorial provinces of the Atlantic Ocean: Evaluation of inter-annual variability. Deep Sea Res. Part II: Top. Stud. Oceanogr. 2006, 53, 1530-1547. [CrossRef]

51. Grob, C.; Ulloa, O.; Claustre, H.; Huot, Y.; Alarcon, G.; Marie, D. Contribution of picoplankton to the total particulate organic carbon concentration in the eastern South Pacific. Biogeosciences 2007, 4, 837-852. [CrossRef]

52. Organelli, E.; Dall'Olmo, G.; Brewin, R.J.; Nencioli, F.; Tarran, G.A. Drivers of spectral optical scattering by particles in the upper $500 \mathrm{~m}$ of the Atlantic Ocean. Opt. Express 2020, 28, 34147-34166. [CrossRef]

Publisher's Note: MDPI stays neutral with regard to jurisdictional claims in published maps and institutional affiliations. 